\title{
SAP CONSUMPTION BY THE WHITE-FRONTED WOODPECKER AND ITS ROLE IN AVIAN ASSEMBLAGE STRUCTURE IN DRY FORESTS
}

\author{
M. Gabriela Núñez Montellano'1, Pedro G. Blendinger, and Leandro Macchi \\ Instituto de Ecología Regional and Consejo Nacional de Investigaciones Científicas y Técnicas (CONICET), \\ Universidad Nacional de Tucumán, CC 34, 4107 Yerba Buena, Tucumán, Argentina
}

\begin{abstract}
The White-fronted Woodpecker (Melanerpes cactorum) drills holes in branches and trunks to feed on sap flows, providing an energy-rich food resource for other birds. Here we describe ecological and behavioral traits of the White-fronted Woodpecker related to its sap-feeding habits in the semiarid Chaco of Argentina and explore the structure of the avian assemblage in relation to the sap resource. Sap consumption by the White-fronted Woodpecker and other sap-feeding species was strongly seasonal and positively associated with periods of resource scarcity. The White-fronted Woodpecker actively defended the sap wells from smaller birds. Specialist and facultative nectarivores that assimilate sucrose at a high rate represented an important proportion of sap-feeding birds. In this system of woodpecker, sap, and other sap-feeding species, each species' consumption depends on its physiological and behavioral characteristics as well as on the availability of other food in the surrounding environment.
\end{abstract}

Key words: Chaco semiarid forests, foraging behavior, Melanerpes cactorum, resource defense, sapfeeding species, sucrose assimilation.

\section{Consumo de Savia por Melanerpes cactorum y su Rol en la Estructuración de Ensambles de Aves en Bosques Secos}

Resumen. Melanerpes cactorum perfora ramas y troncos de árboles y arbustos para consumir la savia que fluye de las perforaciones, posibilitando a otras especies de aves el acceso a un recurso de alto contenido energético. En este estudio describimos rasgos de la historia natural de $M$. cactorum relacionados con su alimentación en el Chaco semiárido de Argentina e investigamos la estructuración de ensambles de aves en torno al recurso savia. Para M. cactorum y las especies de aves que consumieron savia, el consumo de savia fue marcadamente estacional, posiblemente asociado a periodos de escasez de recursos. Melanerpes cactorum defendió activamente las perforaciones ante algunas especies de aves cuya masa corporal fue menor a la de los carpinteros. Las especies nectarívoras especialistas y facultativas con alta tasa de asimilación de sacarosa representaron una importante proporción de las aves que consumieron savia. En el sistema carpinteros-savia-aves consumidoras de savia, el consumo de este recurso depende de características fisiológicas y comportamentales de las especies, como así también de la disponibilidad de otros recursos alimenticios en los ambientes que habitan.

\section{INTRODUCTION}

Consumption of phloem sap is infrequent among birds because few species can overcome the plants' structures and defenses to exploit the resource (O’Donnell and Dilks 1989, Eberhardt 2000). Several species of woodpeckers (Picidae) drill holes in branches and trunks of living trees to have access to the phloem and feed on sap flows. Among these are species of Sphyrapicus (Tate 1973, Daily et al. 1993, Eberhardt 2000), Melanerpes (MacRoberts 1970, Kattan 1988, Genise et al. 1993, Winkler and Christie 2002), Picoides (Kozma 2010), and Campephilus (Schlatter and Vergara 2005). In turn, sap wells made by these woodpeckers are used by other animals, such as insects, birds, and mammals, to reach this energy-rich food resource (Foster and Tate 1966, Holmes 1990, Blendinger 1999). Sap can be a key resource for certain species during periods of resource scarcity (Smith and Russell 1982, Daily et al. 1993, Blendinger 1999, Winkler and Christie 2002), especially for nectarivorous species such as hummingbirds (Trochilidae) and sunbirds (Nectariniidae)] that require high levels of energy (Kilham 1964, O'Donnell and Dilks 1989, Eberhardt 2000, Pejchar and Jeffrey 2004). For these species, sap is a food resource of high energy content, similar to that of flower nectar, because nectar sugars are derived from sucrose translocated in phloem sap (Paton 1980, Gaze and Clout 1983, Nicolson and Fleming 2003).

In semiarid forests of Argentina, the White-fronted Woodpecker (Melanerpes cactorum) drills wells in living branches and trunks of trees and shrubs to feed on sap flows. This species may have a key role in avian community organization because it allows other species access to sap during

Manuscript received 21 October 2011; accepted 10 July 2012.

1E-mail: nunez_gabriela@yahoo.com.ar

The Condor, Vol. 115, Number 1, pages 93-101. ISSN 0010-5422, electronic ISSN 1938-5422. @ 2013 by The Cooper Ornithological Society. All rights reserved. Please direct all requests for permission to photocopy or reproduce article content through the University of California Press's Rights and Permissions website, http://www.ucpressjournals.com/ reprintInfo.asp. DOI: 10.1525/cond.2012.110175 
months of low productivity (Blendinger 1999), which coincide with autumn (May-June) and winter (July-August), when the availability of arthropods, flowers, and fruits declines $(\mathrm{Ca}-$ ziani 1996, Codesido and Bilenca 2004). Fifteen species of birds, diverse in ecological attributes and taxonomic affinities, have been reported to feed on sap from wells in arid and semiarid environments in western Argentina (Genise et al. 1993, Blendinger 1999), including species as highly dependent on energy-rich resources as the Glittering-bellied Emerald (Chlorostilbon aureoventris), which closely tracks trees with active wells (Macchi et al. 2011).

Here we describe ecological and behavioral traits of the White-fronted Woodpecker related to its feeding habits in the semiarid Chaco of Argentina and explore the structure of the avian assemblage with respect to the sap resource provided by the White-fronted Woodpecker. Specifically, (1) we investigated the seasonal diet of the White-fronted Woodpecker, with special emphasis on sap consumption. Sap is the major source of water and energy for the White-fronted Woodpecker during periods of resource shortage in autumn and winter (Blendinger 1999), so we expect a marked seasonal pattern in sap consumption in semiarid Chaco forests. We also investigated (2) sap consumption by other birds that use the woodpecker's sap wells, seasonality in their use of this resource, and their capacity to assimilate sucrose as a functional factor determining this interaction. Both specialist and facultative nectar-feeding birds (e.g., hummingbirds and orioles, respectively; Macchi et al. 2011) assimilate sucrose efficiently (Nicolson and Fleming 2003), so we expect these species to consume sap more frequently than other species during periods of scarce resources. (3) Finally, we evaluated aggressive interactions between the White-fronted Woodpecker and other species that approach sap wells to feed on sap flows. We expected interspecific aggression only against species that use the same resources and are potential competitors (Moore 1978, Murray 1981), especially against species smaller than the White-fronted Woodpecker (Blendinger 1999).

\section{METHODS}

\section{STUDY AREA}

The study was conducted in Rivadavia Banda Sur $\left(24^{\circ} 11^{\prime}\right.$ $\mathrm{S}, 62^{\circ} 53^{\prime} \mathrm{W}$ ), located in the province of Salta, Argentina, in the semiarid Chaco of the Chaco phytogeographical province. The climate is subtropical with warm summers and temperate winters. The maximum absolute summer temperature recorded in South America, $48.9^{\circ} \mathrm{C}$, was registered at Rivadavia Banda Sur (Karlin et al. 1994). The mean annual temperature ranges between 22 and $23^{\circ} \mathrm{C}$, with mean values of $28^{\circ} \mathrm{C}$ and $16^{\circ} \mathrm{C}$ for the hottest (January) and coldest (July) months, respectively. Annual rainfall is low $(650 \mathrm{~mm}$ from 1941 to 1990; http//www.inta.gov.ar), falling mainly between November and March (Minetti 1999). The vegetation is characterized by sparse secondary forests and shrublands subjected to anthropogenic disturbances such as fire, logging, and overgrazing. Soils are saline and range from poorly drained to seasonally flooded. Our sampling sites were located along a strip about $100 \mathrm{~m}$ wide surrounding ponds in forest sectors characterized by a higher density of tall trees and an understory with lower light levels and higher humidity than in the rest of the vegetation matrix. The water level in these ponds varied significantly by season; by the end of the dry season their surface area was reduced by $>75 \%$. The upper tree stratum ( 8 to $11 \mathrm{~m}$ ) is dominated by Prosopis nigra and Aspidosperma quebracho-blanco and the columnar cactus Stetsonia coryne. The intermediate stratum (4 to $8 \mathrm{~m}$ ) harbors mainly Bulnesia sarmientoi, Geoffroea decorticans, Prosopis ruscifolia, Ziziphus mistol, Ruprechtia triflora, and Tabebuia nodosa, whereas the shrub stratum is dominated by Maytenus vitis-idaea, Capparis salicifolia, and C. speciosa.

\section{DIET OF THE WHITE-FRONTED WOODPECKER}

We sampled in six surveys in total, from 2007 to 2011, at the following seasons: autumn (May-June), winter (JulyAugust), late winter (end of September), spring (late October-early November), late spring (December), and summer (February). At Rivadavia Banda Sur, the Whitefronted Woodpecker lives in flocks that maintain permanent territories, in which all the individuals feed together and cooperate in territorial defense and care of nestlings (Macchi et al. 2011). We identified 10 groups of White-fronted Woodpeckers and delimited their territories; for that purpose, we mist-netted and color-banded the birds. In each sampling period, we observed each group for 2 or 3 days, during the first $4 \mathrm{hr}$ of the morning and the last $3 \mathrm{hr}$ of the afternoon. We invested a total of $1029 \mathrm{hr}$ looking for and following individual birds and groups throughout the study site, recording their successive locations with a geographical positioning system (GPS, Garmin Etrex Legend). For each bout of foraging, defined as the total period between detection of a White-fronted Woodpecker eating and its shift in food item, we recorded the resource eaten, time feeding in minutes, and, when the bird used a plant resource, the species used. During autumn, late winter, late spring, and summer, we recorded the tree on whose sap the birds fed and marked it with a metal tag.

\section{SAP CONSUMPTION BY OTHER BIRDS}

In each sampling period, during each bout of a woodpecker's foraging (see above), we recorded other birds that fed on sap, identifying the species and considering as an instance of feeding any visit of an individual from the moment it arrived at the sap well to consume sap to the moment it left. Because all observations were made during bouts of woodpecker foraging, there may be a bias in the frequency of sap consumption by other species, particularly those attacked by 
woodpeckers. However, most of the day one or more woodpeckers remained near the sap wells, so the effect of woodpecker presence was consistent, and this potential bias was similar throughout the study.

We compared the observed assemblage of sap-feeding species with diversity of potentially sap-feeding birds in the forest. We considered potential sap feeders those birds belonging to ecological or taxonomic groups with known records of sap consumption. That is, we excluded carnivorous, terrestrial, and nocturnal species, species not capable of digesting sucrose (families Turdidae and Mimidae), and species with body mass $>100 \mathrm{~g}$, as well as species recorded only once or rarely. At Rivadavia Banda Sur, we made an inventory of all the species recorded during the study by direct observation and identification of vocalizations.

We classified sap-feeding species as specialist nectarivores (those consuming nectar as their primary food source), facultative nectarivores (generalists that regularly feed on nectar but also include fruits and arthropods in their diet), and occasional nectarivores (those feeding mainly on insects, grain. or fruit and using nectar only occasionally). Published data on the diet of the birds of the Chaco is scarce, so to categorize the species we rely on our field knowledge of food consumption and nonspecific literature (e.g. Canevari et al. 1991, Ridgely and Tudor 1989, 1994) plus previous classifications of nectar-feeding birds including species of the same families (Nicolson and Fleming 2003, Lotz and Schondube 2006).

On the basis of the literature, we classified sap-feeding species according to their efficiency in assimilation of sucrose (the major sugar component of sap); when we failed to gather information on the species, we used data of species of the same genus or family (Lotz and Schondube 2006 and references therein). We used assimilated mass coefficient as an estimator of assimilation efficiency (Karasov 1990, Martínez del Rio 1990).

To evaluate intra- and interspecific interactions associated with sap consumption, on each visit of a bird to a sap well, we identified the species and classified its encounter with the White-fronted Woodpecker according to its response as (1) defense of sap wells, when woodpeckers chased the visitor or made movements (hopping, fluttering, or a combination of both) that drove away individuals of the same or other species; (2) passive encounter, when woodpeckers neither chased the intruder nor showed aggressive behavior; (3) escape, when the woodpecker was driven away from the wells by other individuals of the same or other species. To analyze the relationship between a bird's body mass and frequency of aggressive encounters with the Whitefronted Woodpecker, we considered species of body mass and smaller than that of White-fronted Woodpecker (30 g) separately. We calculated species' mean body mass from unpublished data from our previous work and from data on birds captured in northwestern Argentina from the database of the Centro Nacional de Anillado de Aves de Argentina (CENAA; Bird Banding Center of Argentina).

\section{STATISTICAL ANALYSES}

We used a general linear model to compare the time spent by the White-fronted Woodpecker feeding on sap wells by period, followed by a post hoc test of least significant difference to identify significant differences among periods. We used a chi-squared contingency table to evaluate the frequency of interactions associated with sap consumption between the White-fronted Woodpecker and smaller or larger birds. We present descriptive statistics as percentages, ranges, and means, with significance set at $\alpha=0.05$.

\section{RESULTS}

\section{DIET OF THE WHITE-FRONTED WOODPECKER}

The diet of the White-fronted Woodpecker was diverse and varied seasonally; throughout the year, the species consumed varying proportions of sap, arthropods, fruits, seeds, nectar, and floral structures (complete flowers and anthers) (Fig. 1). Sap consumption differed by season $(F=14.09$, df $=5,49$, $P<0.001)$, with significant differences among winter, late winter-spring, and late spring-summer (Fig. 1). The main foraging activity during autumn and winter was sap feeding, representing between $86 \%$ and $93 \%$ of total foraging time (Fig. 1). By the end of winter, sap still was the principal food item ( $78 \%$ of foraging time), whereas in spring, late spring, and summer, the diet of the White-fronted Woodpecker was more diverse, including sap, arthropods, fruits, and flower structures (Fig. 1).

Throughout the study, the woodpeckers fed on sap of five to nine plant species per territory (mean 6.5). We recorded their consuming sap of 12 species: a columnar cactus (Stetsonia coryne), three shrubs (Capparis salicifolia, C. speciosa, Achatocarpus praecox), and nine trees (Bulnesia sarmientoi, Prosopis ruscifolia, Prosopis sp., Chloroleucon foliolosum, Ziziphus mistol, Schinopsis lorentzii, Ruprechtia apetala, and Aspidosperma quebracho-blanco). Six species (Stetsonia coryne, Capparis salicifolia, B. sarmientoi, P. ruscifolia, Z. mistol, and A. quebracho-blanco) were consumed in all the seasons. Composition of plant species used for sap feeding varied by sampling period (Fig. 2). Prosopis ruscifolia was the most commonly consumed species during the dry season (autumn to early spring, $28 \%$ to $85 \%$ of observations); consumption of this species decreased toward the end of spring. The use of $S$. coryne increased gradually in the wet season (late spring and summer, from $34 \%$ to $61 \%$ of the observations). Consumption of the remaining species was distributed across the sampling periods, with $<1 \%$ to $24 \%$ of the observations of sap consumption in each period (Fig. 2, Appendix; available at http://dx.doi.org/10.1525/ cond.2012.110175). The woodpeckers never consumed sap 


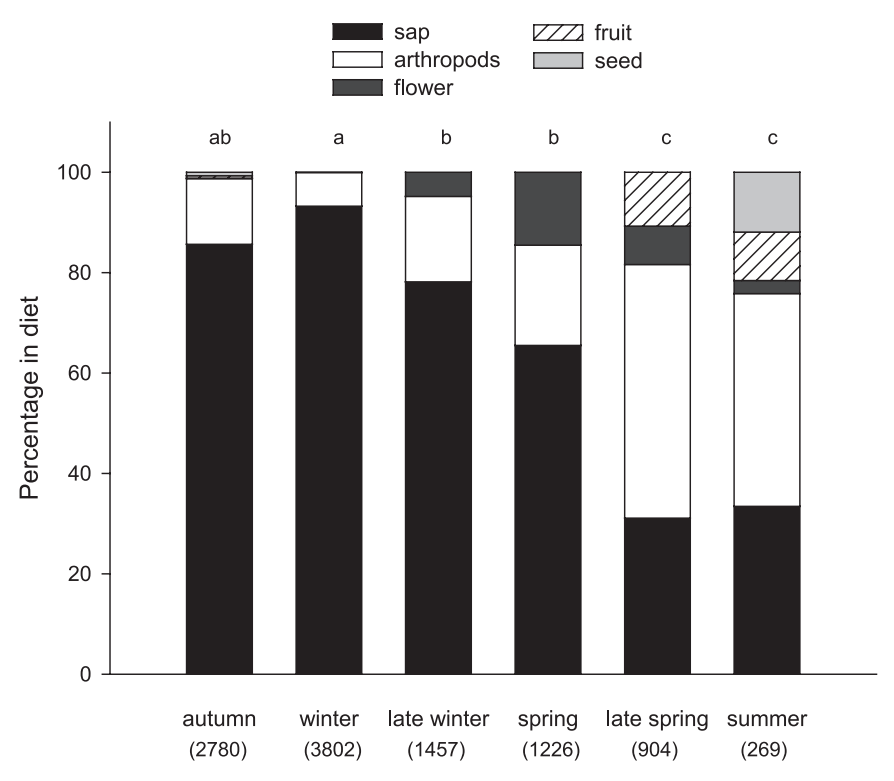

FIGURE 1. Percentage of sap, flowers, fruits, seeds, and arthropods in the diet of the White-fronted Woodpecker in the semiarid Chaco during six periods of the year, expressed as total time of observations of foraging in minutes on each item. For each period, the total time of observation of foraging in minutes is indicated in parentheses. Different letters indicate significant differences in sap consumption by period (post hoc test of least significant differences, following a general linear model, $P<0.05$ ).

of the other 15 species of trees in their territories (Maytenus vitis-idaea, Jatropha hieronymi, Parkinsonia aculeata, Geoffroea decorticans, Chloroleucon tenuiflorum, Cercidium praecox, Maclura tinctoria, Ceiba chodatii, Capparis tweediana, C. retusa, Ruprechtia triflora, Quiabentia verticillata, Opuntia quimilo, Cereus forbesii, and Tabebuia nodosa).

Several members of each group frequently fed on sap together, spending 1 to 39 min (mean $3 \mathrm{~min} 45 \mathrm{sec}$ ) per tree in drilling and reactivating wells and actually feeding. The range of the number of woodpeckers per group was 3.0 to 4.4. During autumn, late winter, and late spring, each group used three to ten trees, concentrated their sap feeding on a single tree of the territory ("focal tree"), and used the other trees ("satellite trees") less frequently (Fig. 3). During this period, nine species were focal trees, Prosopis ruscifolia being the most frequent (35\%). In summer, each group of woodpeckers used one to three trees of six species, allocating $80 \%$ of their time feeding on sap to the focal tree. In autumn, territories covered 0.8 to $2.1 \mathrm{ha}(n=10)$, and were larger in summer, but in summer we recorded sap consumption only occasionally.

The White-fronted Woodpecker fed on arthropods (larvae, ants, and flying insects) by using diverse foraging techniques; drilling of the bark and dead wood of trees and shrubs and gleaning from the bark surface and under the loose bark of trees were the most frequently used techniques $(91 \%$ of

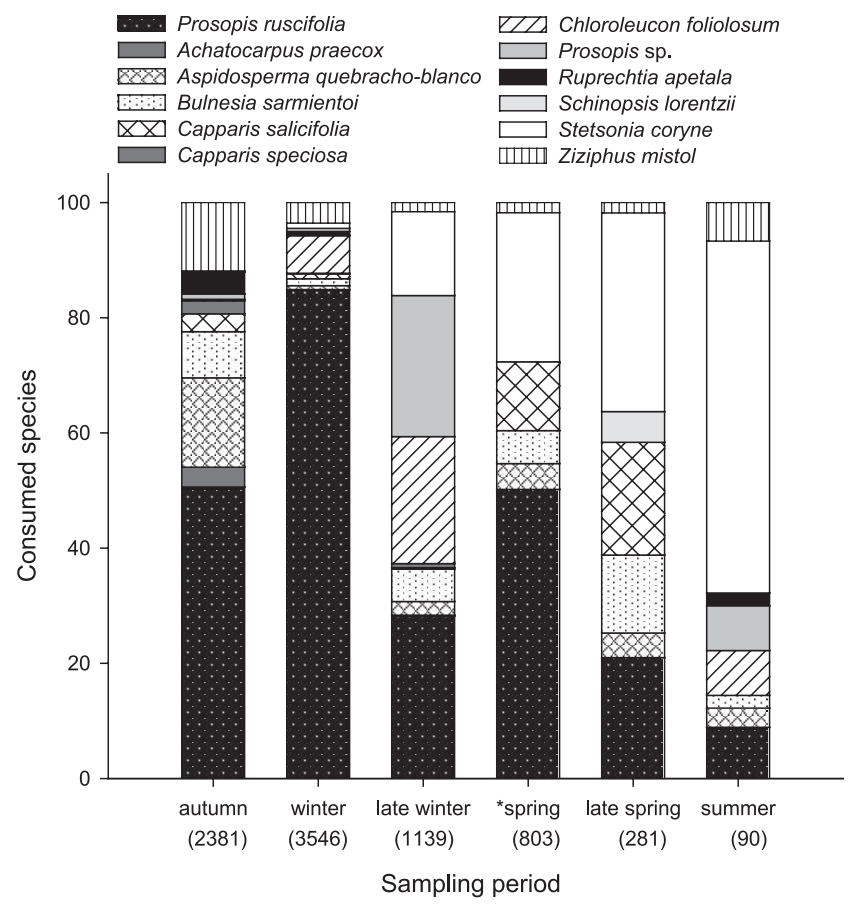

FIGURE 2. Plant species from which the White-fronted Woodpecker consumed sap in 10 territories in the semiarid Chaco during six periods of the year, expressed as percentage of time invested in sap consumption during the period (total time of observation of sap feeding in minutes is indicated in parentheses). *Data for spring include only five territories, so spring data cannot be compared those for other seasons because of the difference in plants available.

observations of arthropod consumption). We also recorded consumption of arthropods from the ground (6\%) and in epiphytes (2\%), principally bromeliads of the genus Tillandsia, by woodpeckers searching on the surface of leaves and in the center of the plant. Another foraging behavior observed was flycatching (1\%), mainly from branches of $S$. coryne and, to a lesser degree, from trunks of dead trees; flycatching was more frequent at sunset, when the group concentrated near roosting sites (typically cavities in $S$. coryne).

The White-fronted Woodpecker consumed floral structures by ingesting nectar and pollen of S. coryne ( $80 \%$ of observations of flower consumption) and $O$. quimilo (8\%) and whole flowers of Capparis salicifolia (11\%) and C. tweediana (1\%). Fruits on which we observed the White-fronted Woodpecker feeding comprised the fruits of C. speciosa ( $41 \%$ of observations of fruit ingestion), the pulp of legumes of Prosopis sp. (32\%), and, to a lesser degree, fruits of the cacti Cereus forbesii $(15 \%)$, S. coryne (9\%) and $O$. quimilo (3\%). In all cases, the White-fronted Woodpecker perched on the fruit and extracted pieces of pulp; from cacti, pieces of pulp were eaten along with the seeds. In summer and autumn, woodpeckers consumed seeds of Capparis salicifolia; this activity represented $12 \%$ and $<1 \%$, respectively, of the time allocated to foraging. To consume these seeds, birds inserted them in bark crevices or dry cactus, which were used as 


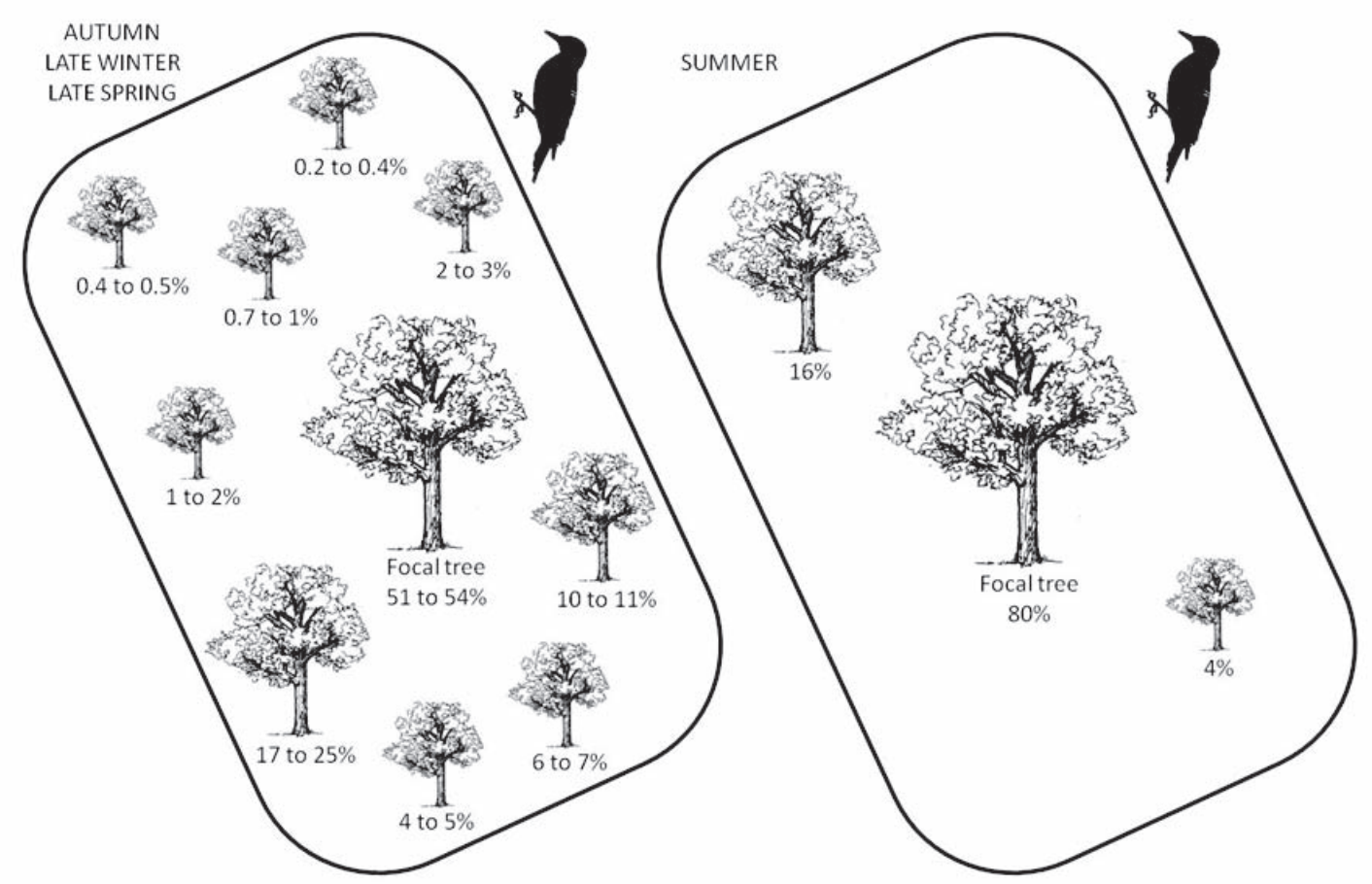

FIGURE 3. Use of focal and satellite trees whose sap the White-fronted Woodpecker consumed in the semiarid Chaco. Percentages are the mean minimum and maximum percentage of time spent in each tree from ten territories. Left: values combining data for autumn, late winter, and late spring; right: values during summer.

anvils, where they pecked the seeds until they drilled a hole in the hard cover to consume the endosperm.

\section{SAP FEEDING BY OTHER BIRDS}

We recorded 15 species of 11 families consuming sap from wells drilled by woodpeckers, representing $18 \%$ of the avian assemblage recorded in forest at Rivadavia Banda Sur (85 species of potential forest sap-feeding birds $<100 \mathrm{~g}$ ); one of the species was a specialist nectarivore, five were facultative nectarivores, and the nine remaining species were occasional nectarivores (Table 1). Sap consumption was markedly seasonal, concentrated in autumn and winter. In autumn, $28 \%$ of observed instances of sap consumption by the White-fronted Woodpecker occurred in the presence of 13 bird species that took advantage of that resource. This proportion decreased to $10 \%$ in winter, when we observed 10 other species feeding on sap, and $<1 \%$ in spring and late spring, when we observed only four other species feeding on sap (Table 1)

In autumn and winter, the species visiting the wells most frequently were the Glittering-bellied Emerald and Blackcapped Warbling-Finch (Table 1). The Epaulet Oriole and Golden-billed Saltator also fed on sap frequently but at a rate varying by season.

\section{SUCROSE ASSIMILATION IN SAP-FEEDING BIRDS}

The known efficiency of sucrose assimilation in bird families that consumed sap from wells drilled by White-fronted
Woodpeckers ranges from 0 to $100 \%$ (Table 1). While there are no sucrose-assimilation data for the species that we recorded consuming sap, there are data available for other species of the genera Chlorostilbon (Golden-crowned Emerald, C. auriceps) and Icterus (Streak-backed Oriole, I. pustulatus).

We recorded 8 species with a high efficiency of assimilation $(>90 \%)$ and 2 species with lower efficiency $(<90 \%)$ (Table 1). We failed to categorize the remaining sap-feeding species ( 5 species) because there are no published data on sucrose assimilation for the Picidae, Polioptilidae, or Emberizidae; for the Furnariidae, data are available for the genus Cinclodes only.

\section{AGGRESSIVE INTERACTIONS IN DEFENSE OF WELLS}

We recorded 447 encounters between White-fronted Woodpeckers and other birds of the same or different species that consumed sap from wells drilled by woodpeckers (Fig. 4); $97 \%$ of the encounters occurred in autumn and winter. Of the total of encounters, 257 (58\%) were intraspecific ( $n=$ $46)$ or interspecific $(n=211)$ aggressive interactions involving the defense of sap wells by woodpeckers, $167(37 \%)$ were passive, nonaggressive interactions, and in $23(5 \%)$ of the encounters, the target woodpecker was driven away from the sap wells.

The type of interaction of with the White-fronted Woodpecker was associated with the body mass of sap-feeding 
TABLE 1. Bird species that consumed sap from wells drilled by the White-fronted Woodpecker in four periods of the year in the semiarid Chaco, Argentina.

\begin{tabular}{|c|c|c|c|c|c|c|}
\hline \multirow[b]{2}{*}{ Family and species } & \multirow[b]{2}{*}{$\begin{array}{c}\text { Nectar } \\
\text { consumption }\end{array}$} & \multicolumn{4}{|c|}{ Visits $^{\mathrm{a}}$} & \multirow[b]{2}{*}{$\begin{array}{l}\text { Sucrose-assimilation } \\
\text { efficiency }\end{array}$} \\
\hline & & $\begin{array}{l}\text { Autumn } \\
(3524 \mathrm{~min}) \\
n=285\end{array}$ & $\begin{array}{c}\text { Winter }{ }^{\mathrm{b}} \\
(4209 \mathrm{~min}) \\
n=88\end{array}$ & $\begin{array}{c}\text { Spring } \\
(1810 \mathrm{~min}) \\
n=9\end{array}$ & $\begin{array}{l}\text { Late spring }^{\mathrm{b}} \\
(2330 \mathrm{~min}) \\
n=2\end{array}$ & \\
\hline Nonpasserines & & & & & & 90 to $100 \%$ \\
\hline Psittacidae & & & & & & 90 to $100 \%$ \\
\hline $\begin{array}{l}\text { Monk Parakeet } \\
\text { (Myiopsitta monachus) }\end{array}$ & occasional & $6 \%(16)$ & $6 \%(5)$ & & & \\
\hline Trochilidae & & & & & & 90 to $100 \%$ \\
\hline $\begin{array}{l}\text { Glittering-bellied Emerald } \\
\text { (Chlorostilbon aureoventris) }\end{array}$ & specialist & $35 \%(99)$ & $24 \%(21)$ & & $50 \%(1)$ & 97 to $99 \%(C$. canivetti $)$ \\
\hline \multicolumn{7}{|l|}{ Passerines } \\
\hline Furnariidae & & & & & & 0\% (Cinclodes spp.) \\
\hline $\begin{array}{l}\text { Narrow-billed Woodcreeper } \\
\text { (Lepidocolaptes } \\
\quad \text { angustirostris) }\end{array}$ & occasional & $<1 \%(1)$ & & & & \\
\hline Tyrannidae & & & & & & $50 \%$ \\
\hline $\begin{array}{l}\text { Greater Wagtail-Tyrant } \\
\text { (Stigmatura budytoides) }\end{array}$ & occasional & $13 \%(36)$ & & & & \\
\hline Polioptilidae & & & & & & No data available \\
\hline $\begin{array}{l}\text { Masked Gnatcatcher } \\
\text { (Polioptila dumicola) }\end{array}$ & occasional & $2 \%(7)$ & & & & \\
\hline Thraupidae & & & & & & 98 to $100 \%$ \\
\hline $\begin{array}{l}\text { Red-crested Cardinal } \\
\text { (Paroaria coronata) }\end{array}$ & occasional & $1 \%(3)$ & $10 \%(9)$ & $11 \%(1)$ & & \\
\hline $\begin{array}{l}\text { Blue-and-yellow Tanager } \\
\text { (Thraupis bonariensis) }\end{array}$ & facultative & $5 \%(14)$ & $8 \%(7)$ & & & \\
\hline $\begin{array}{l}\text { Sayaca Tanager } \\
\text { (Thraupis sayaca) }\end{array}$ & facultative & & & $89 \%(8)$ & & \\
\hline Incertae sedis & & & & & & No data available \\
\hline $\begin{array}{l}\text { Grayish Saltator } \\
\text { (Saltator coerulescens) }\end{array}$ & occasional & $1 \%(2)$ & & & & \\
\hline $\begin{array}{l}\text { Golden-billed Saltator } \\
\text { (Saltator aurantiirostris) }\end{array}$ & occasional & $1 \%(3)$ & $18 \%(16)$ & & $50 \%(1)$ & \\
\hline Emberizidae & & & & & & No data available \\
\hline $\begin{array}{l}\text { Black-capped } \\
\text { Warbling-Finch } \\
\text { (Poospiza melanoleuca) }\end{array}$ & occasional & $15 \%(42)$ & $14 \%(12)$ & & & \\
\hline Cardinalidae & & & & & & No data available \\
\hline $\begin{array}{l}\text { Hepatic Tanager } \\
\text { (Piranga flava) }\end{array}$ & occasional & & $1 \%(1)$ & & & \\
\hline Parulidae & & & & & & 85 to $90 \%$ \\
\hline $\begin{array}{l}\text { Tropical Parula } \\
\text { (Setophaga pitiayumi) }\end{array}$ & facultative & $4 \%(12)$ & $8 \%(7)$ & & & \\
\hline Icteridae & & & & & & 50 to $97 \%$ \\
\hline $\begin{array}{l}\text { Epaulet Oriole } \\
\text { (Icterus cayanensis) }\end{array}$ & facultative & $17 \%(49)$ & $8 \%(7)$ & & & $\begin{array}{l}98 \% \text { (Icterus } \\
\text { pustulatus) }\end{array}$ \\
\hline Fringillidae & & & & & & 50 to $97 \%$ \\
\hline $\begin{array}{l}\text { Purple-throated Euphonia } \\
\text { (Euphonia chlorotica) }\end{array}$ & facultative & $<1 \%(1)$ & $3 \%(3)$ & & & \\
\hline
\end{tabular}

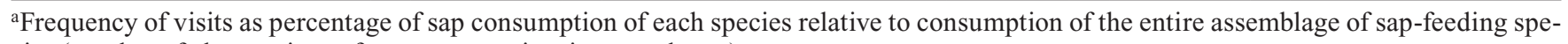
cies (number of observations of sap consumption in parentheses).

${ }^{\mathrm{b}} n$, total number of observed instances of sap consumption; the time of observation of active wells in parentheses. No species other than the White-headed Woodpecker observed consuming sap observed in late winter (2194 min) and summer (730 min).

cFrom Lotz and Schondube (2006) and references therein. 


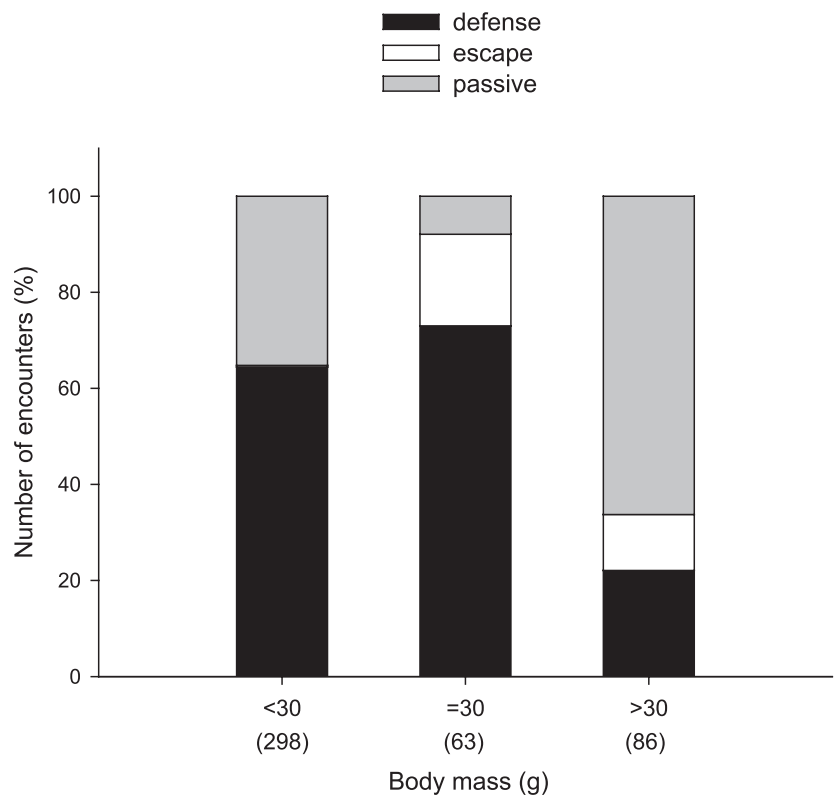

FIGURE 4. Percentage of encounters between birds that visited wells drilled by the White-fronted Woodpecker to feed on sap. This estimate includes passive encounters and aggressive encounters that resulted in defense of wells or escape, with individuals of body mass lower than, similar to, or higher than that of the woodpecker $(30 \mathrm{~g})$. Species $<30$ g: Glittering-bellied Emerald, Greater Wagtail-Tyrant, Masked Gnatcatcher, Black-capped Warbling-Finch, Hepatic Tanager, Tropical Parula, Epaulet Oriole, and Purple-throated Euphonia; $>30$ g: Monk Parakeet, Narrow-billed Woodcreeper, Red-crested Cardinal, Blue-and-yellow Tanager, Sayaca Tanager, Golden-billed Saltator, and Grayish Saltator. Number of encounters is indicated in parentheses.

species $\left(\chi^{2}=102.2, \mathrm{df}=4, P<0.001\right)$. Defense from birds with body mass $\geq 30 \mathrm{~g}$ was less frequent than expected $(22 \%, n=19)$, while passive encounters were more frequent than expected $(66 \%, n=57)$. During encounters with conspecifics, escape behavior by woodpeckers was more frequent than expected $(19 \%$, $n=12$ ). Most interactions (64\%) of White-fronted Woodpeckers with birds $<30 \mathrm{~g}$ of body mass were aggressions (Fig. 4). White-fronted Woodpeckers were attacked and driven off from the wells by the Monk Parakeet (3 instances), Golden-billed Saltator (6), Grayish Saltator (1), and Epaulet Oriole (1).

We also recorded aggressive interactions between species that approached sap wells to eat. This behavior was noticeable in the Epaulet Oriole; indeed, in $48 \%$ of 21 observations of sap feeding involving other species, Epaulet Orioles defended the wells against Glittering-bellied Emeralds (2 instances), Red-crested Cardinals (2), Blue-and-yellow Tanagers (3), Black-capped Warbling-Finches, (2), and a Purple-throated Euphonia (1).

\section{DISCUSSION}

We found that sap is an important food resource for the Whitefronted Woodpecker and several nectar-feeding bird species, and we evaluated the value of sap for birds in association with to functional and behavioral mechanisms. The importance of sap in the diet varied strikingly by season; sap was most important in autumn and winter, possibly because of a seasonal decrease in the availability of alternative resources as arthropods, flowers, and fruits in the semiarid Chaco (Caziani 1996, Codesido and Bilenca 2004). These seasonal variations influenced the behavior of the White-fronted Woodpecker, which had to allocate time and energy to the production and defense of sap wells against other birds. Specialist and facultative nectarivores with a high rate of sucrose assimilation represented an important proportion of sap-feeding species, consuming sap frequently when other food was scarce.

\section{DIET AND SAP FEEDING BY THE WHITE-HEADED WOODPECKER}

Sap feeding was markedly seasonal, as observed in other populations of this species (Genise et al. 1993, Blendinger 1999) inhabiting regions with a climate more adverse than that of our study area. In the Monte desert, Blendinger (1999) suggested that sap feeding by birds might be associated with lack of access to water. However, sap provides more than water, and its ingestion should be related to acquiring energy as well as water. This is supported by the fact that in our study area, near the sites where birds were feeding on sap, there were large ponds used for drinking by numerous birds.

The White-fronted Woodpecker is similar to other species of Melanerpes such as the Acorn Woodpecker ( $M$. formicivorus), Red-headed Woodpecker (M. erythrocephalus), Lewis's Woodpecker (M. lewis), and Gray-breasted Woodpecker (M. hypopolius) with respect to diet plasticity and diversity of food items consumed (Kattan 1988, Winkler and Christie 2002, Leonard and Heath 2010). Sap feeding by the White-fronted Woodpecker peaks during periods of general food shortage and, as availability of other food sources increases, its diet becomes more diverse and includes arthropods, flowers, fruits, and seeds, obtained by different strategies. The ecological plasticity of the White-fronted Woodpecker is evident in behaviors unusual and novel for the family Picidae, such as flycatching, well drilling to gain access to sap, and the use of anvils to consume seeds, which allows the birds to cope with seasonality in food availability. Furthermore, physiological characteristics, such as efficiency of sucrose assimilation, should play a relevant role in the capacity of the species to explore novel resources, such as sap.

Woodpeckers showed a strong feeding preference for the sap of certain tree species, whereas many other plant species were not consumed. They patronized certain core sap-tree species at all seasons and increased the diversity of species used during the periods when the availability of other resources was more limited. In summer, woodpeckers extend their territories, suggesting that the lower diversity of tree on whose sap they feed in summer would reveal a more 
specialized use of the trees present in a territory. Although the identity of core plant species changed over the seasons, P. ruscifolia was the most important and was consumed in a proportion much greater than were the other species. While we cannot state the causes of the White-fronted Woodpecker's preference for P. ruscifolia, selection of plant species by sap-feeding birds might be associated with structural characteristics of the plants, such as size (Pejchar and Jeffrey 2004, Varner et al. 2006, Kozma 2010), plant health (Eberhardt 2000), bark thickness, sap supply, and microenvironmental variables (Pejchar and Jeffrey 2004).

\section{RELATIONSHIP BETWEEN AVIAN ASSEMBLAGE STRUCTURE AND THE USE OF SAP AS A FOOD RESOURCE}

In nectarivorous species, seasonality in sap feeding seems to be controlled by the availability of nectar, with birds using sap in periods of flower shortage (Macchi et al. 2011). Because nectar and sap are similar resources in terms of energy and nutritional characteristics, the sugars present in the sap provide occasional nectarivores with the energy they need at critical periods (Cecere et al. 2011). However, the ability to access sap from plants is not enough, since sucrose, the principal sugar in sap, must be hydrolyzed into simple sugars by enzymes bound to the intestinal membrane (sucrase-isomaltase or sucrase) to be absorbed and assimilated (Schondube and Martínez del Rio 2004). There are no published data on the presence and assimilation capacity of sucrase in the Picidae (Lotz and Schondube 2006; Schondube, pers. comm.). Sap consumption by several species of this family (in the genera Sphyrapicus, Melanerpes, Picoides, and Campephilus) and the capacity to assimilate sucrose by other species of nonpasserines, basal and derived, suggests that the ability to digest this sugar is widespread in nonpasserines and represents an ancestral digestive condition in birds (Lotz and Schondube 2006).

Published values for efficiency of sucrose assimilation in families of sap-feeding birds are high. Hummingbirds' requirements for energy can be met only with high rates of energy intake and sucrose assimilation (Karasov et al. 1986). This fact would explain the high frequency of sap feeding by hummingbirds we observed. Another species feeding on sap frequently was the Epaulet Oriole. Species of Icterus are the main consumers of nectar of several plant species in the Neotropical Region (Ragusa-Netto 2002). Although passerine nectarivores consume less sap than do hummingbirds, because of their lower metabolic rates, the amount of sucrose that they can digest might be enough to meet their daily energetic requirements (Schondube 2003).

The White-fronted Woodpecker defends sap wells actively against some other birds that approach the wells to consume sap, probably attempting to reduce the time and energy costs involved in drilling and activating wells. The defense of sap wells was facultative, as shown by an apparent cost-benefit balance. A woodpecker's decision to drive a bird away or remain passive when it approached the wells was, as we predicted, related to the intruder's body size, an important factor in dominance hierarchies (Huntingford and Giles 1987). These results are consistent with those from other sites at which the White-fronted Woodpecker interacts with different bird assemblages. In the open forest of the Chaco Serrano it kept the Greater Wagtail-Tyrant away from the sap wells, whereas a larger species, the Brown Cacholote (Pseudoseisura lophotes) drove the woodpecker away (Genise et al. 1993). In the Monte desert, Blendinger (1999) reported a clear inverse relationship between body mass of bird species visiting wells and frequency of aggressive encounters with the White-fronted Woodpecker.

\section{CONCLUSION}

The ability to have access to sap may be particularly relevant to coping with the seasonality typical of semiarid climates of temperate regions, where sap represents a highly valued energy-rich resource available year round, buffering temporal variations in food resources. In the semiarid Chaco, the White-fronted Woodpecker is the only bird able to overcome plants' structures and defenses to feed on phloem sap. Although woodpeckers maintain active sap wells throughout the year, sap is their main food resource during the autumn-winter period of food shortage. Other birds, mostly nectar-feeding species, use sap only during periods of lower resource abundance. Among these species, physiological traits such as the ability to assimilate sucrose may be as or more important than foraging behavior or external morphology in determining sap exploitation.

\section{LITERATURE CITED}

Blendinger, P. G. 1999. Facilitation of sap-feeding birds by the White-fronted Woodpecker (Melanerpes cactorum) in the Monte desert, Argentina. Condor 101:402-407.

Canevari, M., P. Canevari, G. R. Carrizo, G. Harris, J. RodriGUez Mata, And R. J. Straneck. 1991. Nueva guía de las aves argentinas, vol. 2. Fundación Acindar, Buenos Aires.

CAZIANI, S. M. 1996. Interacción plantas-aves dispersoras de semillas en un bosque chaqueño semiárido. Ph.D. dissertation, University of Buenos Aires, Argentina.

Cecere, J. G., F. Spina, S. Jenni-Eiermann, and L. Boitani. 2011. Nectar: an energy drink used by European songbirds during spring migration. Journal of Ornithology 152:923-931.

Codesido, M., AND D. N. BilenCA. 2004. Variación estacional de un ensamble de aves en un bosque subtropical semiárido del Chaco argentino. Biotropica 36:544-554.

Daily, G. C., P. R. Ehrlich, And N. M. Haddad. 1993. Double keystone bird in a keystone species complex. Proceedings of the National Academy of Sciences, USA 90:592-594.

EberhardT, L. S. 2000. Use and selection of sap trees by Yellowbellied Sapsuckers. Auk 117:41-51.

Foster, W. L., AND J. TATE. 1966. The activities and coactions of animals at sapsucker trees. Living Bird 5:87-113.

Gaze, P. D., AND M. N. Clout. 1983. Honeydew and its importance to birds in beech forests of south island, New Zealand. New Zealand Journal of Ecology 6:33-37.

Genise, J. F., R. J. Straneck, and P. Hazeldine. 1993. Sapsucking in the White-fronted Woodpecker Melanerpes cactorum. Ornitología Neotropical 4:77-82. 
Holmes, R. T. 1990. Food resource availability and use in forest bird communities: a comparative view and critique, p. 387-393. In A. Keast [ED.], Biogeography and ecology of forest bird communities. SPB Academic Publishing, The Hague, the Netherlands.

HuntingFord, F., AND N. GILES. 1987. Individual variation in antipredator responses in the three-spined stickleback (Gasterosteus aculeatus). Ethology 74:205-210.

KARASOV, W. H. 1990. Digestion in birds: chemical and physiological determinants and ecological implications. Studies in Avian Biology 13:391-415.

Karasov, W. H., D. Phan, J. M. Diamond, and F. L. Carpenter. 1986. Food passage and intestinal nutrient absorption in hummingbirds. Auk 103:453-464.

Karlin, O. U., L. A. Catalán, And R. O. Coirini. 1994. La naturaleza y el hombre en el Chaco seco. Proyecto GTZ - Desarrollo agroforestal en comunidades rurales del noroeste argentino. Colección Nuestros Ecosistemas, Salta, Argentina.

KatTAN, G. 1988. Food habits and social organization of Acorn Woodpeckers in Colombia. Condor 90:101-106.

Kilham, L. 1964. The relations of breeding Yellow-bellied Sapsuckers to wounded birches and other trees. Auk 81:520-527.

Kozma, J. M. 2010. Characteristics of trees used by White-headed Woodpeckers for sap feeding in Washington. Northwestern Naturalist 91:81-86.

Leonard, D. L., AND J. A. Heath. 2010. Foraging strategies are related to skull morphology and life history traits of Melanerpes woodpeckers. Journal of Ornithology 151:771-777.

Lotz, C. N., AND J. E. SchOnduBE. 2006. Sugar preferences in nectar- and fruit-eating birds: behavioral patterns and physiological causes. Biotropica 38:3-15.

Macchi, L., P. G. Blendinger, And M. G. NúÑEz Montellano. 2011. Spatial analysis of sap consumption by birds in the Chaco dry forests from Argentina. Emu 111:212-216.

MacRoberts, M. H. 1970. Notes on the food habits and food defense of the Acorn Woodpecker. Condor 72:196-204.

MARTíNEZ DEL RIO, C. 1990. Sugar preferences in hummingbirds: the influence of subtle chemical differences on food choice. Condor 92:1022-1030.

MinetTi, J. L. 1999. Atlas climático del noroeste argentino. Laboratorio Climatológico Sudamericano, Fundación Zon Caldenius, Tucumán, Argentina.

MoORE, F. R. 1978. Interspecific aggression: toward whom should a mockingbird be aggressive? Behavioral Ecology and Sociobio$\log$ 3:173-176.
Murray, B. G. 1981. The origins of adaptive interspecific territorialism. Biological Reviews 56: 1-22.

Nicolson, S. W., AND P. A. Fleming 2003. Nectar as food for birds: the physiological consequences of drinking dilute sugar solutions. Plant Systematics and Evolution 238:139-153.

O'Donnell, C. F. J., AND P. J. Dilks. 1989. Sap-feeding by the Kaka (Nestor meridionalis) in South Westland, New Zealand. Notornis 36:65-71.

PATON, D. C. 1980. The importance of manna, honeydew and lerp in the diets of honeyeaters. Emu 4:213-226.

Pejchar, L., AND J. JefFrey. 2004. Sap-feeding behavior and tree selection in the endangered Akiapolaau (Hemignathus munroi) in Hawaii. Auk 121:548-556.

Ragusa-NetTo, J. 2002. Exploitation of Erythrina dominguezii Hassl. (Fabaceae) nectar by perching birds in a dry forest in western Brazil. Brazilian Journal of Biology 62:877-883.

Ridgely, R. S., AND G. Tudor. 1989. The birds of South America, vol. 1: the oscine passerines. University of Texas Press, Austin, TX.

Ridgely, R. S., AND G. TudOR. 1994. The birds of South America, vol. 2: the suboscine passerines. University of Texas Press, Austin, TX.

Schlatter, R. P., AND P. Vergara. 2005. Magellanic Woodpecker (Campephilus magellanicus) sap feeding and its role in the Tierra del Fuego forest bird assemblage. Journal of Ornithology 146:188-190.

SchOnduBE, J. E. 2003. Flowerpiercers and hummingbirds: a comparative study of nectar feeding strategies in birds. Ph.D. thesis, University of Arizona, Tucson, AZ.

Schondube, J. E., And C. Martínez del Río. 2004. Sugar and protein digestion in flowerpiercers and hummingbirds: a comparative test of adaptive convergence. Journal of Comparative Physiology 174:263-273.

Smith, A., And R. Russell. 1982. Diet of the yellow-bellied glider Petaurus australis (Marsupialia: Petauridae) in north Queensland. Australian Mammalogy 5:41-45.

TATE, J. 1973. Methods and annual sequence of foraging by the sapsucker. Auk 90:840-856.

Varner, J. M., J. S. Kush, And R. S. Meldahl. 2006. Characteristics of sap trees used by overwintering Sphyrapicus varius (Yellow-bellied Sapsuckers) in an old-growth pine forest. Southeastern Naturalist 5:127-134.

Winkler, H., AND D. A. Christie. 2002. Family Picidae (woodpeckers), p. 296-555. In J. del Hoyo, A. Elliott and J. Sargatal [EDS.], Handbook of the birds of the world, vol. 7: jacamars to woodpeckers. Lynx Edicions, Barcelona. 